\title{
Performance of drippers in two filtering systems using sewage treatment effluent
}

\author{
Alexandre B. Dalri ${ }^{1}$, Gilmar O. Santos ${ }^{2}$, Geffson de F. Dantas ${ }^{1}$, \\ Rogério T. de Faria ${ }^{1}$, José R. Zanini ${ }^{1} \&$ Luiz F. Palaretti ${ }^{1}$ \\ ${ }^{1}$ Universidade Estadual Paulista/Faculdade de Ciências Agrárias e Veterinárias/Departamento de Engenharia Rural. Jaboticabal, SP. E-mail: dalri@fcav.unesp.br \\ (Corresponding author); geffson@hotmail.com; rogeriofaria@fcav.unesp.br; jrzanini@fcav.unesp.br; lfpalaretti@fcav.unesp.br \\ ${ }^{2}$ Universidade de Rio Verde. Rio Verde, GO. E-mail: gilmar@unirv.edu.br
}

\section{Key words:}

wastewater emitters

filter

reuse

irrigation

\begin{abstract}
A B S T R A C T
The objective of this study was to evaluate the performance of three models of drippers using treated sewage effluent, pure and diluted, and two types of filters, screen and disc. The treated sewage effluent used in the experiment was collected from the city's treatment plant. The experiment included 12 lateral lines with three types of emitters to apply pure (100\%) and diluted (50\%) effluent filtered by screen and disc filters. The combination of those factors set the treatments: T1 (50\% effluent diluted in fresh water filtered by a screen filter); T2 (50\% effluent diluted in fresh water filtered by a disc filter); T3 (pure effluent filtered by a screen filter); T4 (pure effluent filtered by a disc filter). The results showed that the flat type emitter is less sensitive to clogging, the disc filter is the most suitable to prevent clogging and the use of pure or diluted sewage effluent increases the drippers' flow rate coefficient of variation.
\end{abstract}

Palavras-chave:

água residuária

emissores

filtro

reuso

irrigação

\section{Desempenho de gotejadores sob dois sistemas de filtragem utilizando efluente de tratamento esgoto}

\section{R E S U M O}

Objetivou-se, neste trabalho, avaliar o desempenho de três modelos de gotejadores de fluxo normal utilizando não apenas o efluente de esgoto tratado puro e diluído mas também dois tipos de filtro, tela e disco. O efluente de esgoto tratado utilizado no experimento foi proveniente da estação de tratamento da cidade. Esta unidade experimental foi composta por 12 linhas laterais com três modelos de gotejadores, dois modelos de filtro e se utilizou, como água de irrigação, o efluente de esgoto tratado puro (100\%) e diluído em água (50\%). Para cada modelo de gotejador foram definidos os tratamentos, sendo: T1 (efluente diluído em 50\% com água subterrânea e uso de filtro de tela); T2 (efluente diluído em $50 \%$ com água subterrânea e uso de filtro de disco); T3 (efluente $100 \%$ e uso de filtro de tela); T4 (efluente $100 \%$ e uso de filtro de disco). Os resultados permitem afirmar que há modelos de gotejadores menos susceptíveis ao entupimento, sendo o gotejador de pastilha menos sensível ao entupimento. O filtro de disco é o mais indicado para prevenir o entupimento. $\mathrm{O}$ uso de efluente de esgoto puro ou diluído aumenta o coeficiente de variação de vazão dos gotejadores. 


\section{INTRODUCTION}

The use of treated sewage effluent (TSE) in agriculture through irrigation is a very important element in the policies and strategies of water resource management in Brazil, which can contribute to transforming the negative image of sewage for the society into an environmentally viable and safe resource (Fonseca et al., 2007).

Drip irrigation systems are the most indicated for the disposal of wastewaters, because of the high application uniformity and low risk of contamination of the agricultural product for the operators of the system (Dazhuang et al., 2009; Duran-Ros et al., 2009). Drip irrigation has advantages in TSE application, because the water applied by the system does not come into direct contact with the crop.

The main disadvantage of the drip system is the high susceptibility to clogging of the drippers (Batista et al., 2013), but physical, chemical and biological treatments, as well as the development of dripper's labyrinths specific for the use with TSE can minimize the risk of clogging, making its application viable. Li et al. (2009), studying the effect of sewage effluent on six models of drippers, observed that there are drippers more susceptible to clogging.

Emitter clogging is a serious problem associated with drip irrigation, because it damages water application uniformity, it is difficult to detect and the cleaning or substitution of the clogged drippers is costly (Nakayama \& Bucks, 1991). In most studies with wastewaters, clogging has a direct effect on the reduction of the flow rate of the drippers. Tajrishy et al. (1994) observed the formation of biofilm resulting from the bacterial mucilage and suspended solids in drippers supplied with secondary domestic sewage effluent. On the other hand, Taylor et al. (1995) observed that $90 \%$ of the drippers showed clogging due to TSE application. Silva et al. (2012), studying the use of wastewater generated in cashew nut processing as irrigation water on the clogging of three models of drippers, claimed that the dripper with greatest labyrinth length was more susceptible to clogging.

Therefore, studies have shown that drippers have different potentials to clogging according to the quality of the water and their technical manufacturing characteristics.

This study aimed to evaluate the performance of three models of drippers with normal flow using pure and diluted treated sewage effluent and two types of filter, screen and disc.

\section{Material AND Methods}

The experiment was carried out at the Faculty of Agrarian and Veterinarian Sciences of Jaboticabal (FCAV-UNESP), located in the municipality of Jaboticabal-SP, Brazil. The treated sewage effluent (TSE) used in the experiment came from the sewage treatment station (STS) of Jaboticabal.

The chemical concentrations of the TSE used in the experiment and expressed in $\mathrm{mg} \mathrm{L}^{-1}$ were: $\mathrm{NO}_{3}=4.4, \mathrm{NH}_{3}=$ $38.8, \mathrm{~N}_{\text {total }}=53.7, \mathrm{P}=0.9, \mathrm{~K}=16.6, \mathrm{Ca}=14.0, \mathrm{Mg}=5.0, \mathrm{Fe}_{\text {Total }}$ $=0.42, \mathrm{Mn}=0.1, \mathrm{Zn}=0.4, \mathrm{Na}=54.8$, TOC (total organic carbon $)=36.3$, mean $\mathrm{pH}=7.2$, electrical conductivity $=0.45 \mathrm{dS}$ $\mathrm{m}^{-1}$ and $\mathrm{SAR}=3.2$. The evaluations followed the methodology proposed by the American Public Health Association (2005). For microbiological parameters, the following mean values were found: TC (total coliforms) $=19,867 \mathrm{MPN} \mathrm{100-1} \mathrm{mL}$ and

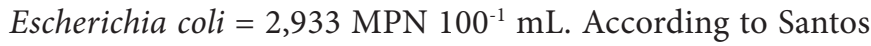
(2015), there is no alteration of the chemical characteristics of this TSE along the year.

The experimental unit was composed of 12 lateral lines, three models of drippers, two models of filter, using as irrigation water pure TSE (100\%) and TSE diluted in water (50\%), totaling 12 treatments. For each model of dripper, the following treatments were defined: T1 (50\% TSE diluted in fresh water filtered by a screen filter); T2 (50\% TSE diluted in fresh water filtered by a disc filter); T3 (pure TSE filtered by a screen filter); and T4 (pure TSE filtered by a disc filter).

The TSE underwent physical treatment: disc filter or screen filter. The brand of the filters was Amiad and the dimension of the filtering opening for both filters, disc and screen, was $130 \mu \mathrm{m}$ (120 mesh).

Three models of drippers were installed for the screen filter and the same three drippers were installed for the disc filter, with 50 and $100 \%$ TSE. The service pressure at the beginning of the lateral lines was maintained at $100 \mathrm{kPa}$.

The drippers used in the experiment were Durázio (G1), Chapin (G2) and QueenGil (G3). These drippers do not have flow rate-compensation device and their nominal flow rates at a pressure of $100 \mathrm{kPa}$ are $1.50,1.11$ and $1.80 \mathrm{~L} \mathrm{~h}^{-1}$, respectively.

The drippers adopted in the experiment have different manufacturing characteristics. The dripper Durázio (G1) is formed by gluing a rigid tape, which contains the labyrinth, on the wall of the pipe during the extrusion process. The dripper Chapin (G2) is manufactured with the same material of the pipe, a similar characteristic to the dripper QueenGil (G3), but the latter has a lateral water outlet when placed on the soil.

The drip irrigation pipes G1 and G2 were arranged on the soil surface, so that the water outlet was facing up.

The first evaluation using clean water occurred after the experiment was installed, time equal to zero. Every $160 \mathrm{~h}$, new flow rate tests were applied in the same drippers, previously identified. Ten drippers per lateral line (LL) were evaluated, totaling 120 drippers in the 12 lateral lines. The system was daily actuated until completing $40 \mathrm{~h}$ of irrigation per week, totaling $800 \mathrm{~h}$ of operation of the drippers at the end of the experiment.

In the evaluation, collectors were placed below the drippers. The collection time was $3 \mathrm{~min}$. Each dripper was isolated by strings in order to correctly collect the flow rate of the only dripper selected and also to avoid the interference of the flow rate from the neighboring drippers.

The performance of the drippers was evaluated using the following equations: relative flow rate (Qr) Eq. 1 and flow rate coefficient of variation (CVQ) Eq. 2.

$$
\mathrm{Qr}=\frac{\mathrm{Q}_{\mathrm{i}}}{\mathrm{Q}_{0}} \cdot 100
$$

where:

Qr - relative flow rate of the emitters, \%;

$\mathrm{Q}_{0} \quad$ - flow rate of the emitter at the time $\mathrm{t}=0, \mathrm{~L} \mathrm{~h}^{-1}$; 
$\mathrm{Q}_{\mathrm{i}} \quad$ - flow rate of the emitter at the time $\mathrm{i}, \mathrm{L} \mathrm{h}^{-1}$; and, 100 - conversion factor.

$$
\mathrm{CVQ}=\frac{\mathrm{S}}{\mathrm{q}_{\mathrm{m}}} \cdot 100
$$

where:

CVQ - flow rate coefficient of variation, \%;

$\mathrm{S} \quad$ - standard deviation of the sample, $\mathrm{L} \mathrm{h}^{-1}$; and,

$\mathrm{q}_{\mathrm{m}} \quad$ - mean flow rate of the sample, $\mathrm{L} \mathrm{h}^{-1}$.

In each treatment, 10 drippers were analyzed and the observed flow rate of each dripper was considered as a replicate.

A completely randomized design (CRD) was used, considering the observed flow rate of each dripper as a plot and using $\mathrm{F}$ test in the analysis of variance and $\mathrm{t}$-test to compare the means of the flow rates of the drippers. The statistical analyses were performed using the program Assistat (Silva \& Azevedo, 2016).

\section{Results AND Discussion}

Figure 1A represents the effect of the treatment T1 (diluted TSE and screen filter) on the flow rate of the drippers Durázio (G1), Chapin (G2) and QueenGil (G3) until 800 h of operation. The dripper G3 showed reduction of flow rate from $320 \mathrm{~h}$ of operation on, accentuating this reduction at the time of $800 \mathrm{~h}$. In percentage terms, the flow rate reduction in this dripper was $29.9 \%$ considering the time interval from 0 to
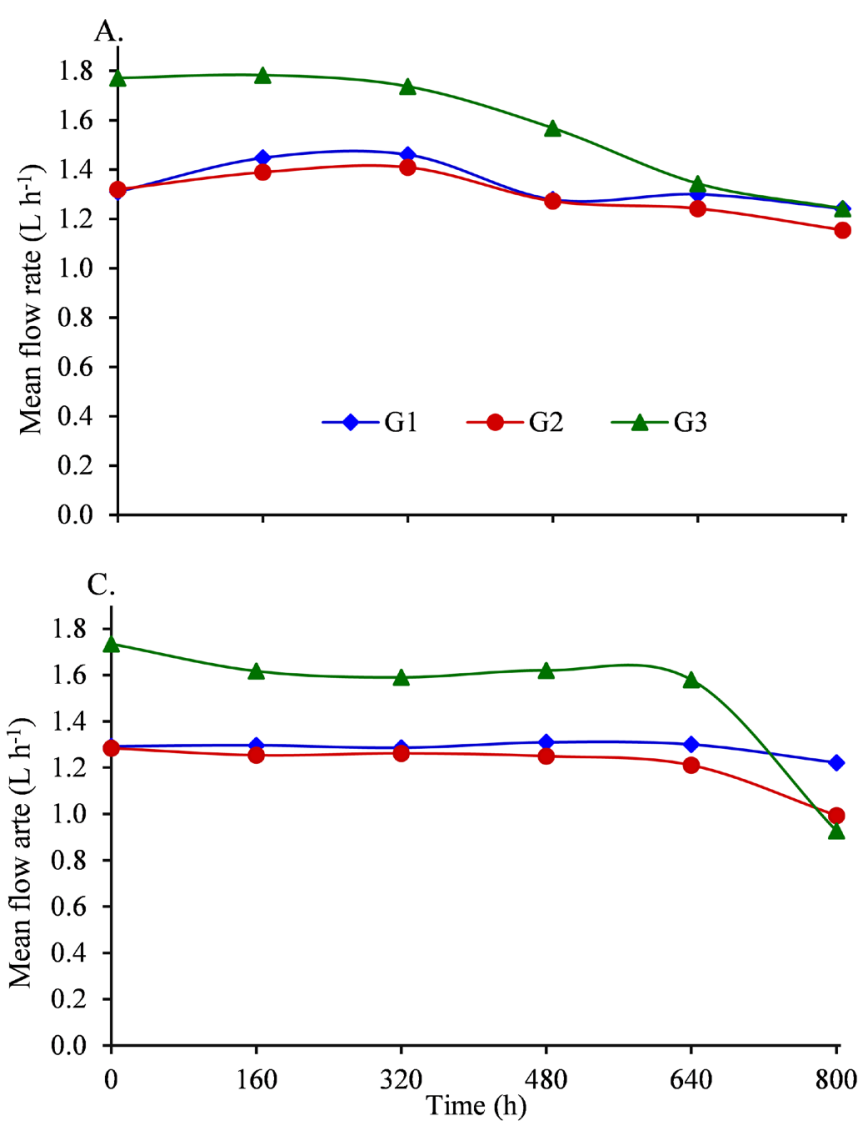

Figure 1. Relationship of time of operation of the drippers Durázio (G1), Chapin (G2) and QueenGil (G3), and the flow rate observed in the treatments: Diluted treated sewage effluent (TSE) and screen filter (A), diluted TSE and disC filter (B), pure TSE and screen filter (C) and pure TSE and disc filter (D)
800 h. According to Batista et al. (2010), the use of TSE in drip irrigation caused a reduction of only $4.56 \%$ in the dripper's flow rate, i.e., comparatively, the flow rate reduction of the dripper QueenGil was high.

For the models G1 and G2, there was a reduction of flow rate, but it was not so evident as in the model G3; thus, in this case, the interpretation was adopted in the four analyzed treatments. In Figure 1B, which presents the flow rate data of the treatment T2 (pure TSE and disc filter), the flow rate of the drippers also varied over time, showing a behavior very similar to that of $\mathrm{T} 1$. This characteristic demonstrates, at first, a similarity between the treatments $\mathrm{T} 1$ and $\mathrm{T} 2$, which is an indication that the type of filter, screen or disc, does not either inhibit or favor the clogging of the dripper, and the dripper G3 was the most susceptible to clogging.

The dripper G1, which has the rigid tape, showed superior performance compared with the others tested in this experiment. This is an indication that the emitters for the use with treated sewage effluent must be similar to this model.

The results of the test of comparison of means between the operation time of the dripper, type of filtering and with or without TSE dilution are shown in Tables 1, 2 and 3.

Based on the mean flow rate of the dripper G2 in the treatments T1, T2 and T3, it can be claimed that there was significant difference between the times 0 and $800 \mathrm{~h}$. In the treatment T4 (pure TSE and disc filter), the initial flow rate (time zero) did not differ statistically from the final flow rate $(800 \mathrm{~h})$, i.e., there was no significant reduction of the flow rate.
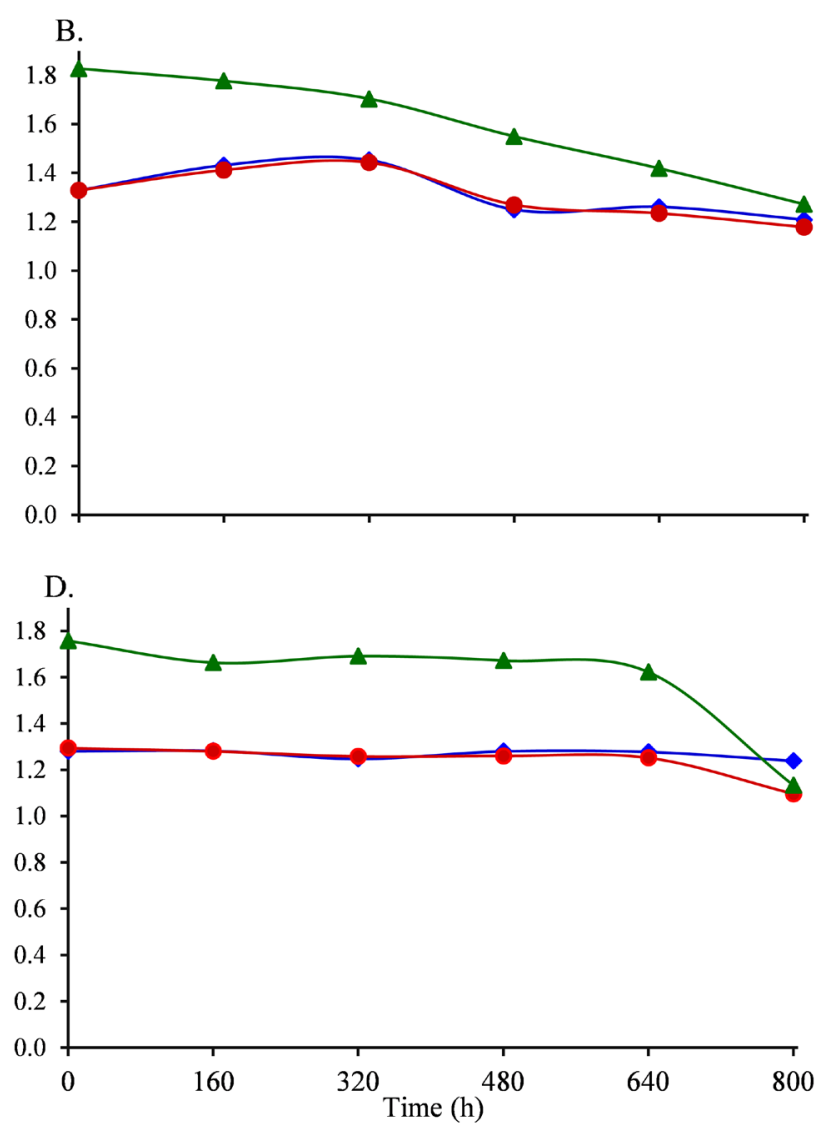
According to the mean flow rate of the drippers in the treatments T1 and T2 (Table 1), it can be affirmed that the flow rate of the drippers was negatively altered, i.e., there was reduction of flow rate until $480 \mathrm{~h}$ in T1 and $800 \mathrm{~h}$ in T2. The addition of water to the TSE probably led to the formation of precipitates, which favor the clogging of the dripper's labyrinth.

The dripper G2, which is built with the same material of the pipe, also showed significant reduction of flow rate over time and as a function of the treatments of TSE dilution and type of filter. The statistical analyses of this model of dripper are shown in Table 2.

For the model G2, there was a significant reduction of flow rate over time in the four treatments, i.e., with the use of screen or disc filter and TSE dilution, the flow rate of the dripper decreases.

It is noted that, in T4 (pure TSE and disc filter), there was a significant reduction in the flow rate of the model G2 only when the operation time of the emitter reached $800 \mathrm{~h}$. In general, again the disc filter showed better efficiency of filtering and prevention of emitter clogging.

The dripper G3, whose mean flow rates are presented in Table 3, did not show significant difference for the values of flow rate as a function of the treatments $\mathrm{T} 1, \mathrm{~T} 2, \mathrm{~T} 3$ and $\mathrm{T} 4$, i.e., the TSE dilution and the type of filter did not inhibit its flow rate significantly. These results confirm those observed by PuigBargués et al. (2010), who did not find significant difference in the effect of using TSE on the flow rate of two emitters, one pressure-compensating and the other of normal flow.

Based on the effect of time on flow rate reduction, it can be claimed, with a $95 \%$ confidence level, that the use of TSE

Table 1. Mean flow rate of the dripper Durázio (G1) over time and as a function of the type of filter and trated sewage effluent (TSE) dilution

\begin{tabular}{rcccc}
\hline Time & \multicolumn{4}{c}{ Flow rate $\left(\mathbf{L ~}^{-1}\right)$ of the dripper - Durázio* } \\
\cline { 2 - 5 } (h) & T1 & T2 & T3 & T4 \\
0 & $1.310 \mathrm{bA}$ & $1.329 \mathrm{bA}$ & $1.292 \mathrm{aA}$ & $1.280 \mathrm{aA}$ \\
160 & $1.447 \mathrm{aA}$ & $1.432 \mathrm{aA}$ & $1.297 \mathrm{aB}$ & $1.282 \mathrm{aB}$ \\
320 & $1.460 \mathrm{aA}$ & $1.453 \mathrm{aA}$ & $1.286 \mathrm{aB}$ & $1.247 \mathrm{aB}$ \\
480 & $1.278 \mathrm{cAB}$ & $1.250 \mathrm{cdB}$ & $1.312 \mathrm{aA}$ & $1.283 \mathrm{aAB}$ \\
640 & $1.300 \mathrm{bA}$ & $1.261 \mathrm{cA}$ & $1.300 \mathrm{aA}$ & $1.277 \mathrm{aA}$ \\
800 & $1.241 \mathrm{cA}$ & $1.209 \mathrm{dA}$ & $1.222 \mathrm{bA}$ & $1.238 \mathrm{aA}$ \\
\hline
\end{tabular}

T1 - Screen filter and diluted TSE, T2 - Disc filter and diluted TSE, T3 - Screen filter and pure TSE and T4 - Disc filter and pure TSE

*Means followed by the same letter, lowercase in the column and uppercase in the row, do not differ statistically by t-test at 0.05 probability level

Table 2. Mean flow rate of the dripper Chapin (G2) over time and as a function of the type of filter and treated sewage effluent (TSE) dilution

\begin{tabular}{rcccc}
\hline Time & \multicolumn{4}{c}{ Flow rate $\left(\mathbf{L ~ h}^{-1}\right)$ of the dripper - Chapin* } \\
\cline { 2 - 5 } (h) & T1 & T2 & T3 & T4 \\
0 & $1.319 \mathrm{bA}$ & $1.329 \mathrm{bA}$ & $1.284 \mathrm{aA}$ & $1.294 \mathrm{aA}$ \\
160 & $1.389 \mathrm{aA}$ & $1.412 \mathrm{aA}$ & $1.254 \mathrm{abB}$ & $1.280 \mathrm{aB}$ \\
320 & $1.409 \mathrm{aA}$ & $1.443 \mathrm{aA}$ & $1.262 \mathrm{abB}$ & $1.280 \mathrm{aB}$ \\
480 & $1.272 \mathrm{bcA}$ & $1.265 \mathrm{cA}$ & $1.253 \mathrm{abA}$ & $1.261 \mathrm{aA}$ \\
640 & $1.242 \mathrm{CA}$ & $1.235 \mathrm{cdA}$ & $1.210 \mathrm{bA}$ & $1.252 \mathrm{aA}$ \\
800 & $1.155 \mathrm{dAB}$ & $1.173 \mathrm{dA}$ & $0.994 \mathrm{cC}$ & $1.096 \mathrm{bB}$ \\
\hline
\end{tabular}

T1 - Screen filter and diluted TSE, T2 - Disc filter and diluted TSE, T3 - Screen filter and pure TSE and T4 - Disc filter and pure TSE

* Means followed by the same letter, lowercase in the column and uppercase in the row, do not differ statistically by t-test at 0.05 probability level
Table 3. Mean flow rate of the dripper QueenGil (G3) over time and as a function of the type of filter and trated sewage effluent (TSE) dilution

\begin{tabular}{ccccc}
\hline Time & \multicolumn{4}{c}{ Flow rate $\left(\mathbf{L ~ h}^{-1}\right)$ of the dripper - G3* } \\
\cline { 2 - 5 } (h) & T1 & T2 & T3 & T4 \\
0 & $1.771 \mathrm{a}$ & $1.827 \mathrm{a}$ & $1.735 \mathrm{a}$ & $1.757 \mathrm{a}$ \\
160 & $1.783 \mathrm{a}$ & $1.777 \mathrm{a}$ & $1.617 \mathrm{a}$ & $1.663 \mathrm{a}$ \\
320 & $1.737 \mathrm{ab}$ & $1.704 \mathrm{ab}$ & $1.590 \mathrm{ab}$ & $1.691 \mathrm{ab}$ \\
480 & $1.568 \mathrm{~b}$ & $1.551 \mathrm{~b}$ & $1.616 \mathrm{~b}$ & $1.672 \mathrm{~b}$ \\
640 & $1.343 \mathrm{C}$ & $1.419 \mathrm{C}$ & $1.580 \mathrm{C}$ & $1.622 \mathrm{C}$ \\
800 & $1.242 \mathrm{~d}$ & $1.272 \mathrm{~d}$ & $0.927 \mathrm{~d}$ & $1.133 \mathrm{~d}$ \\
\hline
\end{tabular}

T1 - Screen filter and diluted TSE, T2 - Disc filter and diluted TSE, T3 - Screen filter and pure TSE and T4 - Disc filter and pure TSE

*Means followed by the same letter in the column do not differ statistically by t-test at 0.05 probability level

as irrigation water significantly reduces the flow rate of the emitter from $480 \mathrm{~h}$ of operation on, i.e., the operation time of this model of dripper was the main characteristic that compromised its functioning.

The relative flow rates of the drippers, expressed by the ratio between the flow rate observed at the time $i$ and the initial flow rate at the time zero, are presented in Figure 2 (A), (B), (C) and (D), for the treatments $\mathrm{T} 1, \mathrm{~T} 2, \mathrm{~T} 3$ and $\mathrm{T} 4$, respectively.

For the drippers $\mathrm{G} 1$ and $\mathrm{G} 2$, the relative flow rate (Qr) did not show reduction until $320 \mathrm{~h}$ in the four treatments.

The treatments with diluted TSE (Figure 2A and B) showed a slight increase in the relative flow rate of the drippers G1 and $\mathrm{G} 2$ at the operation time of $320 \mathrm{~h}$. This increase of flow rate was not expected, because the hypothesis was that there would be partial clogging in the drippers.

For this variable of analysis, again the dripper G1 exhibited the best behavior, especially in the treatment T4 (Figure 2D).

Based on the effect of the filter on this variable at the time of $800 \mathrm{~h}$, the mean value of Qr in T3 (screen filter) was $75.1 \%$ and the mean value of $\mathrm{Qr}$ in $\mathrm{T} 4$ (disc filter) was $82.0 \%$, confirming the better performance of the disc filter in comparison to the screen filter.

Capra \& Scicolone (2007), comparing disc filter and screen filter, as in the present experiment, found higher percentage of clogged emitters using disc filter, a result similar to that of the present study. According to these authors, the differences between disc and screen filters with the same dimension of filtration are due to the different filtering mechanisms.

The dripper with lateral water outlet, model G3, showed the worst performance regarding this variable. The value of $\mathrm{Qr}$ at $800 \mathrm{~h}$ was $53.4 \%$ in T3 (screen filter); thus, this model of dripper is not indicated to be used with sewage effluent. Rowan et al. (2013) studied the clogging of four models of dripper subjected to the use with effluent and claimed that there are emitters more susceptible to clogging, confirming the results of the present experiment.

The coefficients of variation obtained in the drippers G1, G2 and G3 are shown in Figure 3 A, B, C and D for the treatments $\mathrm{T} 1, \mathrm{~T} 2, \mathrm{~T} 3$ and T4, respectively. It is observed that, at the time $0 \mathrm{~h}$, the CVQ values were lower in the models $\mathrm{G} 2$ and G3, compared with G1. However, with $800 \mathrm{~h}$ of operation, the drippers G3 and G2 with diluted TSE were the only ones to maintain a regular CVQ value. The drippers G3 and G2, with pure TSE, exhibited an undesirable performance at the end of the test. 
A.

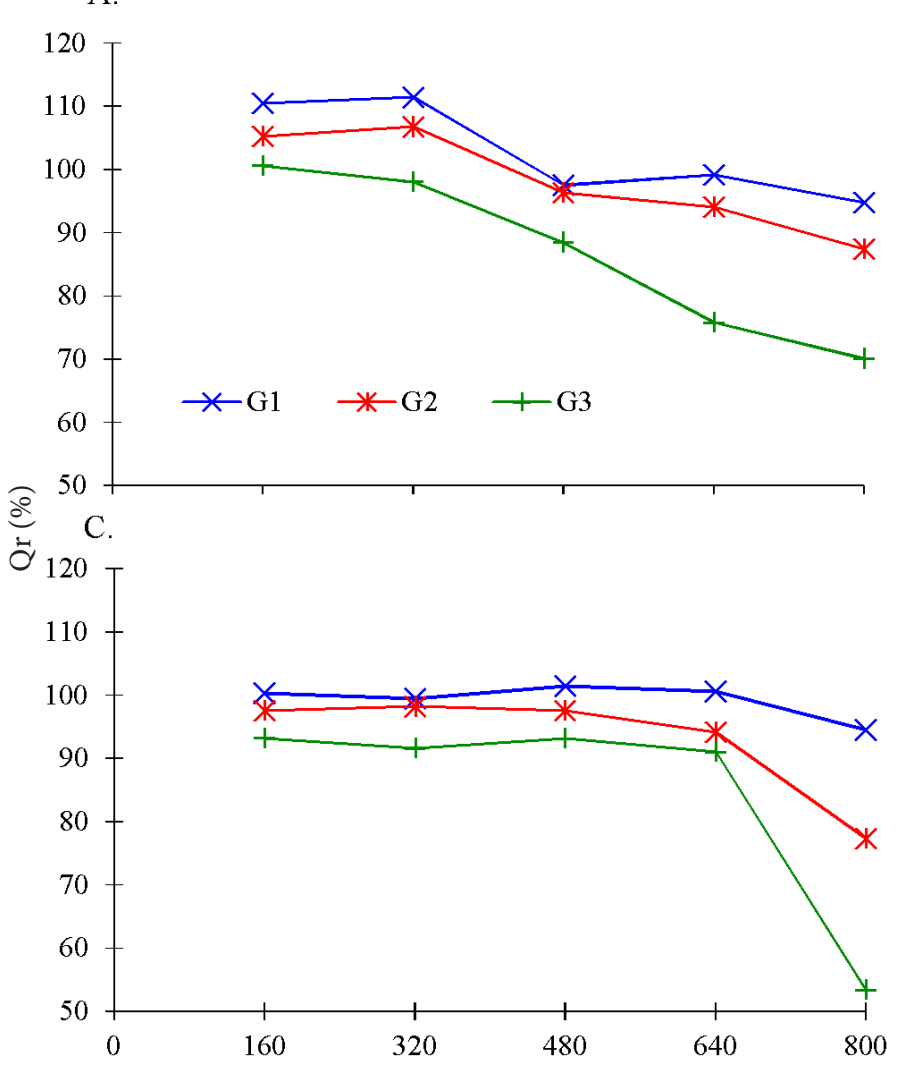

B.

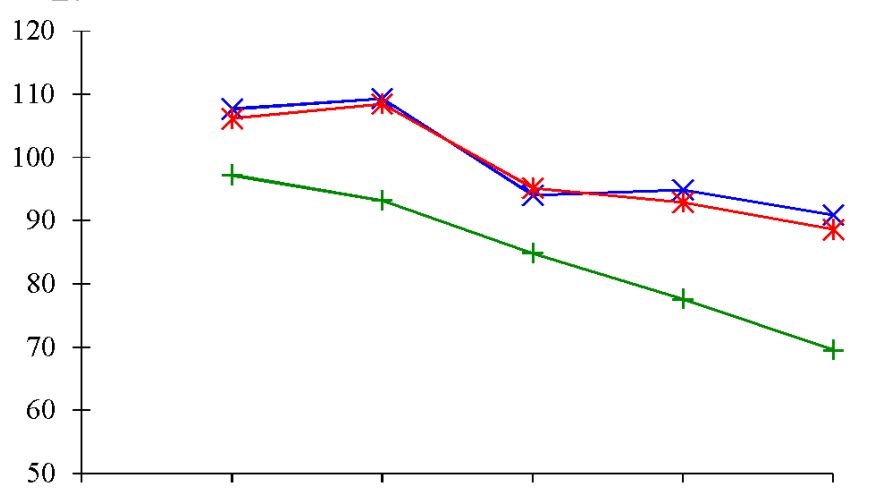

D.

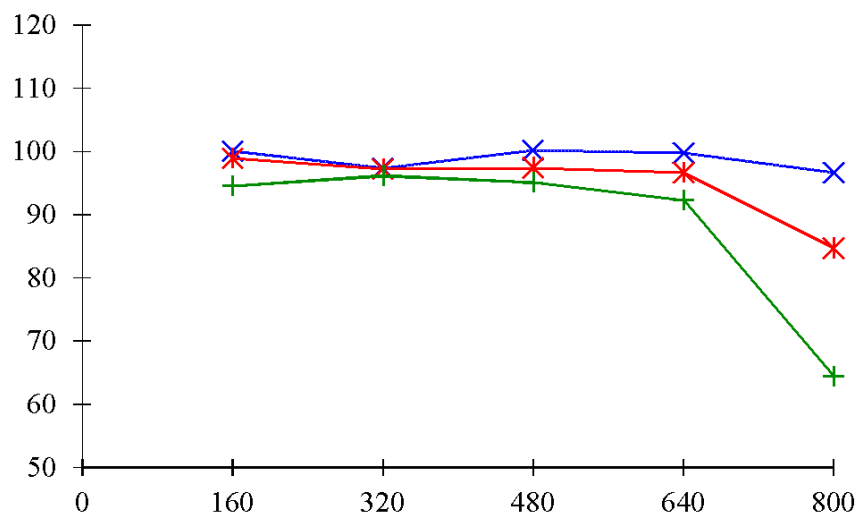

Figure 2. Relative flow rate (Qr) of the drippers Durázio (G1), Chapin (G2) and QueenGil (G3) as a function of the operation time and subjected to the treatments T1 (A) (screen filter and diluted trated sewage effluent - TSE), T2 (B) (disC filter and diluted TSE), T3 (C) (screen filter and pure TSE) and T4 (D) (disc filter and pure TSE)

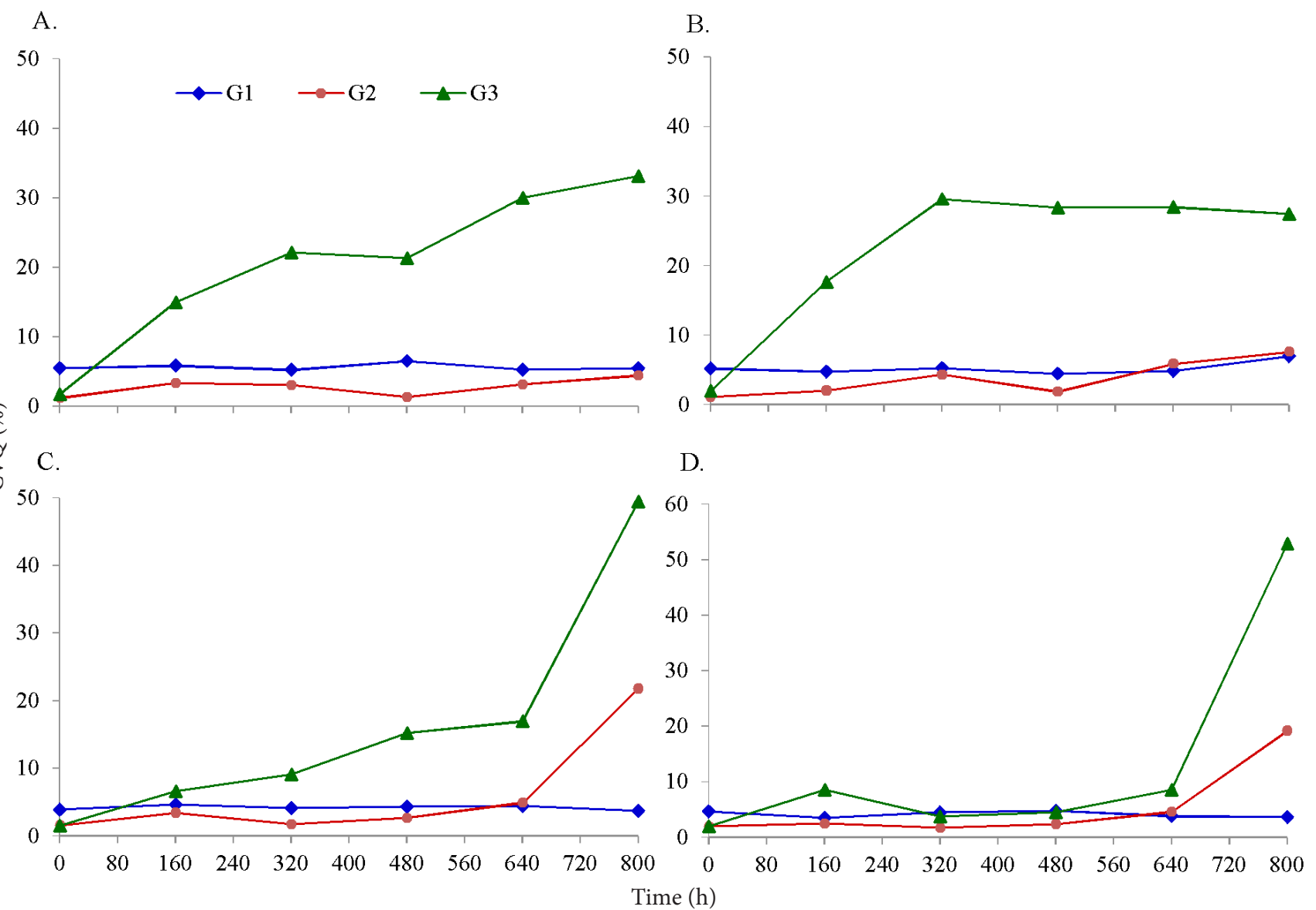

Figure 3. Flow rate coefficient of variation (CVQ) of the drippers Durázio (G1), Chapin (G2) and QueenGil (G3), as a function of the operation time using diluted and pure treated sewage effluent (TSE) with screen and disc filter 
According to the norm NBR ISO 9261 (ABNT, 2006), the drippers must have a CVQ lower than $7 \%$ when new. At the time of $0 \mathrm{~h}$, none of the commercial brands exceeded the 7\% flow rate variation allowed by the norm. Thus, it can be claimed that the three evaluated models are within the specifications required by the NBR ISO 9261; however, at the end of the test, only the model G1 remained with the values within the normative specification.

\section{Conclusions}

1. There are models of drippers less susceptible to clogging using treated sewage effluent, and the dripper with rigid tape is the least sensitive to clogging.

2. The drip irrigation pipe with lateral water outlet, QueenGil, is not indicated to be used with sewage effluent.

3. Disc filters are more efficient to prevent clogging of drippers.

4. Only filter of $130 \mu \mathrm{m}(120 \mathrm{mesh})$ as physical treatment of the treated sewage effluent does not completely prevent the clogging of the drippers.

5. The use of pure or diluted treated sewage effluent increases the drippers' flow rate coefficient of variation.

\section{Literature Cited}

ABNT - Associação Brasileira de Normas Técnicas. NBR ISO 9261: Equipamentos de irrigação agrícola. Emissores e tubos emissores. Especificação e métodos de ensaio. São Paulo: ABNT, 2006. 17p.

APHA - American Public Health Association. Standard methods for the examination of water and wastewater. 21.ed. Washington, D. C.: APHA/AWWA/WEF, 2005. 1134p.

Batista, R. O.; Oliveira, R. A.; Santos, D. B. dos; Oliveira, A. F. M.; Azevedo, C. A. V. de; Medeiros, S. de S. Obstrução e uniformidade de aplicação em sistemas de irrigação por gotejamento aplicandose efluente da suinocultura. Revista Brasileira de Engenharia Agrícola e Ambiental, v.17, p.698-705, 2013. http://dx.doi. org/10.1590/S1415-43662013000700002

Batista, R. O.; Souza, J. A. R. de; Ferreira, D. C. Influência da aplicação de esgoto doméstico tratado no desempenho de um sistema de irrigação. Revista Ceres, v.57, p.18-22. 2010. http://dx.doi. org/10.1590/S0034-737X2010000100004

Capra, A.; Scicolone, B. Recycling of poor quality urban wastewater by drip irrigation systems. Journal of Cleaner Production, v.15, p.1529-1534, 2007. http://dx.doi.org/10.1016/j.jclepro.2006.07.032
Dazhuang, Y.; Zhihui, B.; Rowan, M.; Likun, G.; Shumei, R.; Peiling, Y. Biofilm structure and its influence on clogging in drip irrigation emitters distributing reclaimed wastewater. Journal of Environmental Sciences, v.21, p.834-841, 2009.

Duran-Ros, M.; Puig-Bargués, J.; Arbat, G.; Barragán, J.; Cartagena, F. R. de. Effect of filter, emitter and location on clogging when using effluents. Agricultural Water Management, v.96, p.67-79, 2009. http://dx.doi.org/10.1016/j.agwat.2008.06.005

Fonseca, A. F. da; Herpin, U.; Paula, A. M. de; Victória, R. L.; Melfi, A. J. Agricultural use of treated sewage effluents: Agronomic and environmental implications and perspectives for Brazil. Scientia Agricola, v.64, p.194-209, 2007. http://dx.doi.org/10.1590/S010390162007000200014

Li, J.; Chen, L.; Li, Y. Comparison of clogging in drip emitters during application of sewage effluent and ground water. Transactions of the ASABE, v.52, p.1203-1211, 2009. http://dx.doi. org/10.13031/2013.27797

Nakayama, F. S.; Bucks, D. A. Water quality in drip/trickle irrigation: A review. Irrigation Science, v.12, p.187-192, 1991.

Puig-Bargués, J.; Arbat, G.; Elbana, M.; Duran-Ros, M.; Barragán, J.; Cartagena, F. R. de; Lamm, F. R. Effect of flushing frequency on emitter clogging in microirrigation with effluents. Agricultural Water Management, v.97, p.883-891. 2010.

Rowan, M.; Mancl, K. M.; Tuovinen, O. H. Evaluation of drip irrigation emitters distributing primary and secondary wastewater effluents. Irrigation \& Drainage Systems Engineering, v.2, p.1-7, 2013. http://dx.doi.org/10.4172/2168-9768.1000111

Santos, G. O. Aplicação de efluente de tratamento de esgoto, via aspersão, no solo e em Brachiaria. Jaboticabal: UNESP/FCAV, 2015. 197p. Tese Doutorado

Silva, F. de A. S. e; Azevedo, C. A. V. de. The Assistat Software Version 7.7 and its use in the analysis of experimental data. African Journal of Agricultural Research, v.11, p.3733-3740. 2016. http://doi.doi. org/10.5897/AJAR2016.11522

Silva, K. B. da; Batista, R. O.; Silva, S. K. C.; Dias, N. da S.; Costa, M. S. Efeito de distintas pressões de serviço na determinação da vazão em sistemas de irrigação por gotejamento operando com efluente do processamento da castanha de caju. Revista ACSA, v.8, p.89-96, 2012.

Tajrishy, M.; Hills, D. J.; Tchobanoglous, G. Pretreatment of secondary effluent for drip irrigation. Journal of Irrigation and Drainage Engineering, v.120, p.716-731, 1994. http://dx.doi.org/10.1061/ (ASCE)0733-9437(1994)120:4(716)

Taylor, H. D.; Bastos, R. K. X.; Pearson, H. W.; Mara, D. D. Drip irrigation with waste stabilization pond effluents: Solving the problem of emitter fouling. Water Science Technology, v.31, p.417-424. 1995. 